\begin{tabular}{|c|c|c|c|c|c|c|}
\hline \multirow{4}{*}{ Impact Factor: } & ISRA (India) & $=4.971$ & SIS (USA) & $=0.912$ & ICV (Poland) & $=6.630$ \\
\hline & ISI (Dubai, UAE & $=0.829$ & РИНЦ (Russia & $=0.126$ & PIF (India) & $=1.940$ \\
\hline & GIF (Australia) & $=0.564$ & ESJI (KZ) & $=8.716$ & IBI (India) & $=4.260$ \\
\hline & JIF & $=1.500$ & SJIF (Morocco & $=5.667$ & OAJI (USA) & $=0.350$ \\
\hline
\end{tabular}

\section{SOI: $1.1 /$ TAS $\quad$ DOI: $10.15863 /$ TAS \\ International Scientific Journal Theoretical \& Applied Science}

p-ISSN: 2308-4944 (print) e-ISSN: 2409-0085 (online)

Year: $2020 \quad$ Issue: 03 Volume: 83

Published: $30.03 .2020 \quad \underline{\text { http://T-Science.org }}$
QR - Issue

QR - Article
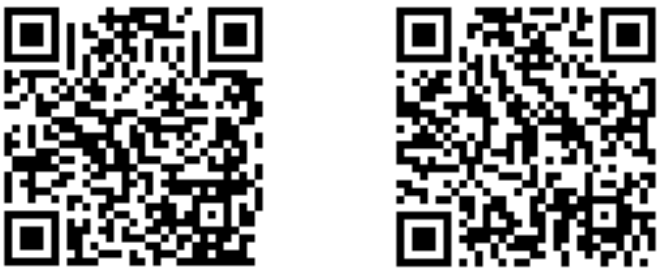

Nasiba Orzuyevna Abdullayeva

The Bukhara Engineering and technological institute A teacher of Foreign Languages Department +99891 440-38-72

nasiba.abdullayeva.2018@mail.ru

\title{
FEATURES OF THE SKILL SET AND THE METHODS USED TO DEVELOP IT
}

\footnotetext{
Abstract: the article provides an overview of the various aspects of techniques and techniques used to develop listening and comprehension skills, as well as practical aspects of reading and writing skills.

Key words: communication, binder, application, iPad, poster; Requests: questions, memorization.

Language: English

Citation: Abdullayeva, N. O. (2020). Features of the skill set and the methods used to develop it. ISJ Theoretical \& Applied Science, 03 (83), 383-386.

Soi: http://s-0-i.org/1.1/TAS-03-83-72

Scopus ASCC: 1203.

Doi: crossef https://dx.doi.org/10.15863/TAS.2020.03.83.72
}

\section{Introduction}

One of the key skills involved in active communication in modern methodology is speaking. Each class is different, so think about some of the key words that your students need to know. These words are words that you encounter in everyday life, and make sure they are directly or indirectly identified. They may or may not know some of these words, so don't hesitate to call them and say a lot of words in the first week. Here are some tips to get started. Materials: desk, book, paper, pencil, pencil, notebook, binder, application, iPad, marker; Rules: Imperative grammar, judgment, should, must, can, render; People: students, teachers, classmates, principal; Classroom: clock, whiteboard, computer, calendar, poster; Requests: questions, need, water, feeling of illness; Honorable words: please thank you; Conversations and Scenes.

\section{II.Literature review}

A great way to introduce or repeat these words is to use them in conversations with pictures. It may take some time to create this or you can find the record already on the Internet. Practice different dialogs between two students, a teacher and a student, or the whole class. Practice the same conversation in each pair, then discuss the interviews as a whole group and answer any questions. Alternatively, different conversations can be given to each pair first and then to the whole class. Make sure all students practice each of the dialogues. If your students have strong knowledge, give them scenarios rather than interviews. Make a written text or give a picture with two people and give them an interview. If you give each pair the same picture and the students present their dialogues for the class, hearing them, given the similarities and differences between the conversations, can lead to larger conversations about different speech.

\section{III.Analysis}

Spy: Another great room for low-income students to explore material in the classroom is the classic I-Spy game. If you want to test your language for more practice, rename the game to "I'm Seeing Something". Before you begin with the student level, you may want to consider some adjectives and descriptive words. If your students' knowledge is low to describe, change the game to Pictionary. A student goes out on a blackboard and you show them the word they want. The student draws a 9-word image on a blackboard and tries to find the words of other students. My corner in the classroom Describe the students: Divide the students into groups and place them in different parts of the room. Together, they should find and identify everything in their corners 


\begin{tabular}{|c|c|c|c|c|c|c|}
\hline \multirow{4}{*}{ Impact Factor: } & ISRA (India) & $=4.971$ & SIS (USA) & $=0.912$ & ICV (Poland) & $=6.630$ \\
\hline & ISI (Dubai, UAE & $=0.829$ & РИНЦ (Russia & $=0.126$ & PIF (India) & $=1.940$ \\
\hline & GIF (Australia) & $=0.564$ & ESJI (KZ) & $=8.716$ & IBI (India) & $=4.260$ \\
\hline & JIF & $=1.500$ & SJIF (Morocec & $=5.667$ & OAJI (USA) & $=0.350$ \\
\hline
\end{tabular}

and then present all the objects in the classroom. They can use dictionaries if they want. Allow students to scroll around the room to allow them to visualize all the objects. Predicting their knowledge: If you do not have a clear idea of your students' level of knowledge, let them show you what they already know, so you don't have to repeat them. Divide your students into groups and let them describe the school using words they already know. Longest Listing Group - Winner! Alternatively, prepare multiple pictures of classroom words and groups should have as many characters as possible. Practice, practice, practice: Use words as often and as quickly as possible. Say, write, and put words in all the appropriate conditions. When the time comes, repeat the word with all students, not just you. Flawless Games: Another very important factor is to make students feel very comfortable using practical vocabulary. Use acting games to increase their familiarity and speed in dictionary memorization. One way to achieve this goal is to play hot potatoes. Pupils stand in a circle and shoot a small object around the circle. If the student accepts the object, he / she should speak within three seconds. If they stop or take more than three seconds, they have to leave the circle. To make it even more difficult, students must leave the circle, even if they repeat what other students have said. You can customize this activity to the level of your students, for example, by using words that start with a single letter or word.

In a traditional classroom practice, one person asks a question and another responds. The question and answer is structured and predictable and there is usually one correct, predetermined answer / 2; 32b./. The purpose of asking and answering is to demonstrate the ability to ask and answer the question. On the contrary, the purpose of real communication, the delivery of telephone messages, the information to perform a task such as receiving or commenting. In real communication, participants must manage uncertainty about what others are saying. Natural communication involves an information gap; each participant has the missing information. In addition, participants may be asked to clarify their meanings or to validate their own ideas to achieve their goals. In order to develop communication skills, teachers need to have a purpose and an information gap and have multiple forms of expression. It does not produce speakers, however. Teachers should integrate with communication activities that allow students to use the language more freely, and to improve accuracy and accuracy.

\section{IV.Discussion}

"Pedagogical skills" as a category has its own scientific basis. The scientific approaches of 1987 1997 led to the following conclusion regarding this extraordinary phenomenon: Pedagogical skill is understood as a bright manifestation of individuality in professional activity. The category of pedagogical skills characterizes a person's individuality in terms of professional activity. The specifics of pedagogical skills in current research are grouped into the following categories: Pedagogical skills (A.S. Belkin, V.I. Zagvyazinsky, N.P. Lebednik, I.A. Zyazyun, T.F. Kuzina, N.V. Kukharev, S.B. Elkanov, A.K. Markova); Pedagogical creativity (V.V. Belich, V.I.Zagvyazinskiy, V.A. Kan-Kalik, N.D.Nikandrov, A.K. Markova, T.V. Frolova, T.Kaloshina, G.F. Poxmelkina, S.Y. Stepanov); Innovation (V.I Zagvyazinskiy, A.K. Markova); Professional knowledge (I.A.Zyazyun, N.P.Lebednik, A.K.Markova); Method of work (A.K. Markova); Innovative activity (E.P. Morozov, P.I. Pidkasistiy, N.V. Yusufbekova); Pedagogical technology (N.E. SHurkova, V.Y. Pityukov, E.A.Osipova); Mastery (N.V. Kuzmina, T.V.Frolova, T.YU.Kaloshina, G.F.Poxmelkina, S.Y.Stepanova). The use of different concepts to describe the same phenomenon in the work of different researchers has different meanings and content aspects. The lack of a single, recognized definition of pedagogical skill in the works of various authors leads to the conclusion that it is a living process of research. The variety of concepts and ideas testifies to the complexity and versatility of this phenomenon. In all definitions, emphasis is placed on the individual, thus reflecting the social nature of pedagogical skills. I.A. Zyazyun and N.A. Lebednik proved the interdependence of a person's social maturity and professional skills. The skill is gradually acquired by students depending on their level of social maturity. The components of social maturity are proportional to the components of pedagogical skills.

The components of a future educator's social maturity include:

- social self-determination; and beliefs;

- the expression of one's pedagogical abilities

- social activism

- improving the ability to work with people and educate others;

- social responsibility is the knowledge that becomes the knowledge of the teacher.

The components of pedagogical skills have been studied in the researches of N.V. Kuzmina, V.A. Slastenin, I.A. Zyazyun, V.I. Zagvyazinsky, G.I. Khozyainov, T.F. Kuzina, A.I. Myashenko, N.P. Lebednik, T. Neuner, Y. Babansky, N.V. Kukharev. They defined the main directions of pedagogical skills in a certain logical sequence.

The basics of pedagogical skills include:

- professional pedagogical knowledge;

- humanism;

- pedagogical techniques; activities;

- experience in professional pedagogical

- pedagogical personality.

Stages of skill development include:

- reproductive (elementary); 


\begin{tabular}{|c|c|c|c|c|c|c|}
\hline \multirow{4}{*}{ Impact Factor: } & ISRA (India) & $=4.971$ & SIS (USA) & $=0.912$ & ICV (Poland) & $=6.630$ \\
\hline & ISI (Dubai, UAE & $=0.829$ & РИНЦ (Russia & $=0.126$ & PIF (India) & $=1.940$ \\
\hline & GIF (Australia) & $=0.564$ & ESJI (KZ) & $=8.716$ & IBI (India) & $=4.260$ \\
\hline & JIF & $=1.500$ & SJIF (Morocce & $=5.667$ & OAJI (USA) & $=0.350$ \\
\hline
\end{tabular}

- creative;

- creative-innovative.

Levels of pedagogical skills are a continuation of the teacher's level of work:

- reproductive (very low);

- flexible (low);

- local (limited);

- modeling (moderately satisfactory).

This level is characterized by high quality in some areas of educational work with students: consistent modeling (high). At this stage, high quality is achieved in all types of pedagogical activities; consistent modeling (higher). It shows a creative approach to all types of activities, looking for ways to increase the effectiveness of the educational process. The components of pedagogical competence reflect the qualitative perspectives required to perform professional duties. Researchers understand a qualification as the ability to perform a system of behaviors effectively in accordance with the purpose and conditions of its implementation. The following skill groups, which form the components of pedagogical skills, are distinguished: design; construction; organization; communication; cognition and reflectivity. In recent years, new views on the category of pedagogical skills have emerged. There was some deviation from the traditional interpretations of pedagogical skills (I.A. Zyazyun, N.V. Kuzmina, V.A. Slastenin). The St. Petersburg School of Pedagogical Researchers describes pedagogical skills as a special case of a person - that is, his / her profession is pedagogy, which in a broad sense is a specific area of work with people.

The basis of pedagogical skill is pedagogical knowledge. Pedagogical knowledge is an integral professional-personal description, defined by the ability and readiness to perform a pedagogical task in accordance with the norms, standards and requirements adopted in a particular historical period. Pedagogical knowledge implies the ability of a person skilled in the field of pedagogy to rationally use all the experience gained by mankind in the work of education and upbringing, which means that he must adequately master the appropriate methods and forms of pedagogical activity and relationships. The main indicator of professional and pedagogical knowledge is the focus on the person. Professional pedagogical knowledge includes the ability to consistently understand the pedagogical reality and to act consistently in it. This quality allows to see the logic of the pedagogical process as a whole and in its entirety, to understand the laws and directions of development of the pedagogical system, to facilitate the construction of purposeful activities. Knowledge requires the mastery of modern pedagogical technologies related to three aspects that are very important for the teacher: interaction with people, cultural communication; be able to receive information in the field of science and process it in accordance with the content of teaching and use it in independent study; be able to share educational information with others.

\section{V.Conclusion}

Vocational and pedagogical knowledge has four main components characterized by:

- person-centered;

- consistent perception of pedagogical reality;

- science orientation;

- mastery of pedagogical technologies.

In today's world of education, there are three types of vocational education filled with component: knowledge, in general, is the activity of the world pedagogical culture The ability to organize on the basis of experiences developed at the level of him and to be able to integrate into pedagogy in our country; interact with their peer experience and innovative experiences ability to communicate; be able to share their experiences and share them with others will be reflected in the qualification.

The professional knowledge of the educator is characterized by creativity. Creativity is a way of life, a multifaceted learning process and goals, content, new pedagogical at the level of technology is the desire and skill to create reality. Creativity is innovative for the teacher helps it adapt to the flow of change. A professional knowledgeable person of any level is capable of pedagogical reflection.

\section{References:}

1. Brown, H. D. (1987). Principles of Language Learning and Teaching, Englewood Cliffs, New Jersey: Prentice-Hall.

2. Adamson, D. (2008). "Inter-language variation in theoretical and pedagogical perspective”, London.

3. Hammerly, H. (1991). "Fluency and accuracy", England.
4. Wilson, J. (2008). How to teach listening, Longman.

5. Thronbury, S. (2005). How to teach speaking, Longman.

6. Harding, K. (2001). "English for specific purposes", Oxford. 


\begin{tabular}{|c|c|c|c|c|c|c|}
\hline \multirow{4}{*}{ Impact Factor: } & ISRA (India) & $=4.971$ & SIS (USA) & $=0.912$ & ICV (Poland) & $=6.630$ \\
\hline & ISI (Dubai, UAE & $=0.829$ & РИНЦ (Russia) & $=0.126$ & PIF (India) & $=1.940$ \\
\hline & GIF (Australia) & $=0.564$ & ESJI (KZ) & $=8.716$ & IBI (India) & $=4.260$ \\
\hline & JIF & $=1.500$ & SJIF (Morocco) & $=5.667$ & OAJI (USA) & $=0.350$ \\
\hline
\end{tabular}

7. Larsen-Freeman, D. (2000). Techniques and principles in language teaching. Oxford: University Press.

8. Richard, J.C., \& Rogers, T.S. (2009). Approaches and methods in language teaching. Cambridge University Press. Retrieved August 20th, 2009.

9. Stern, H. (1983). Fundamental concepts of language teaching, London: Oxford University Press.

10. Harmer, J. (2001). The Practice of English Language Teaching. Harlow: Longman.

11. (2000). Jolly and Bolitho R. Material design. 